\title{
PENGEMBANGAN MODEL MANAJEMEN UNIT PRODUKSI SMK PROGRAM STUDI KEAHLIAN TATA BUSANA DI KABUPATEN SLEMAN
}

\author{
Wahyu Eka Priana Sukmawaty \\ Prodi PTK Vokasi Tata Busana PPs UNY \\ syayoek@yahoo.com \\ Sugiyono \\ Fakultas Teknik Universitas Negeri Yogayakarta \\ sugiyono_1953@yahoo.com \\ Abstrak
}

\begin{abstract}
Salah satu permasalahan krusial yang dihadapi pendidikan kejuruan adalah kompetensi lulusan yang belum sesuai dengan kriteria kualifikasi kemampuan peserta didik menurut standar yang ditentukan. Sejumlah kendala faktual antara lain banyak SMK yang belum memiliki training center, yang memungkinkan siswa SMK dapat melakukan praktik kerja industri. Penelitian ini bertujuan untuk: (1) mengetahui faktor-faktor penghambat pelaksanaan kerja Unit Produksi; (2) menghasilkan model manajemen Unit Produksi yang layak untuk diterapkan; dan (3) mengetahui kelayakan model manajemen Unit Produksi SMK. Penelitian ini menggunakan metode research and development yang terdiri dari tiga tahap: penelitian dan pengumpulan informasi, perencanaan model, dan pengembangan model. Penelitian dilakukan di SMK Negeri 1 Depok, SMK Negeri 2 Godean, SMK Karya Rini, dan SMK Muhammadiyah Berbah. Pengumpulan data penelitian menggunakan wawancara mendalam dan observasi. Hasil penelitian menunjukkan bahwa: (1) pelaksanaan manajemen Unit Produksi SMK program studi Tata Busana masih terdapat beberapa kendala; (2) menghasilkan model manajemen Unit Produksi yang layak untuk diterapkan di SMK Program Studi Keahlian Tata Busana yang terdiri dari dua komponen, yakni Unit Produksi sebagai sumber belajar dan Unit Produksi sebagai sumber pendanaan.; dan (3) hasil uji internal yang dilakukan terhadap pengelola SMK yang terdiri dari SMK Negeri 1 Depok, SMK Negeri 2 Godean, SMK Karya Rini, dan SMK Muhammadiyah Berbah menyimpulkan bahwa sebesar $85 \%$ setuju bahwa model ini efektif jika diimplementasikan.
\end{abstract}

Kata kunci: pengembangan model, manajemen, Unit Produksi SMK

\section{THE DEVELOPMENT OF PRODUCTION UNIT MANAGEMENT MODEL OF CLOTHING DESIGN STUDY PROGRAM AT VOCATIONAL HIGH SCHOOLS IN SLEMAN REGENCY}

\begin{abstract}
One of the crucial problems faced by vocational education was that the graducate compentencies had not match the qualification criteria of the student's ability based on the predetermined standards. Among the factual constraints was that many vocational high schools (SMK) had not possessed a training center which would enable the students to conduct industrial work practice. This study aimed to: (1) determine the factors inhibiting the implementation of the function of the Production Unit; (2) yield production unit management model appropriate to apply; and (3) determine the appropriateness of the production unit management model at SMK. This was a research and development study consisting of three stages: research and information collection, model planning, and model development. The study was conducted in SMK Negeri 1 Depok, SMK 2 Godean, Karya Rini Vocational School, and SMK Muhammadiyah Berbah. The research data were collected using in-depth interviews and observation. The results showed that: (1) the implementation of the production unit management clothing design study program still faced some obstacles; (2) the research generated a management model that deserved to be applied in the clothing design study program. The model suggested two components: a production unit as a source of learning and a production unit as a source of funding; and (3) the result of the internal try-out conducted on the management of vocational high schools consisting of SMK Negeri 1 Depok, SMK 2 Godean, SMK Karya Rini, and SMK Muhammadiyah Berbah concluded that $85 \%$ of the management agreed that this model would be effective if it was implemented.
\end{abstract}

Keywords: model development, management, production unit of vocational high schools 



\section{PENDAHULUAN}

Saat ini permasalahan yang dihadapi pendidikan kejuruan berkisar pada kompetensi lulusan yang belum sesuai dengan kriteria kualifikasi kemampuan peserta didik yang tercantum dalam Peraturan Menteri Pendidikan dan Kebudayaan Pemerintah RI No. 54 Tahun 2013 tentang Standar Kompetensi Lulusan Pendidikan Dasar dan Menengah. Standar kompetensi inilah yang perlu dikembangkan sebagai pilar utama dalam mengatasi masalah kemiskinan dan pengangguran di satu bangsa dan negara.

Sejumlah kendala faktual yang sering diungkapkan kalangan SMK yaitu mereka mengeluhkan industri di Indonesia masih belum banyak yang memiliki training center yang memungkinkan siswa SMK dapat melakukan praktik kerja industri. Inilah alasan yang sering diungkapkan oleh beberapa guru dan kepala sekolah SMK yang ada di Indonesia. SMK sebagai lembaga pendidikan yang menyiapkan tenaga kerja, seharusnya tidak hanya memfokuskan pada penyiapan tenaga untuk mengisi lapangan kerja di industri saja, namun juga disiapkan untuk mengisi lapangan kerja pada sektor informal bahkan disiapkan untuk mandiri yakni menjadi wirausahawan yang mampu untuk menciptakan lapangan kerja bagi dirinya ataupun orang lain sebagai wirausahawan.

Berkaitan dengan penyiapan tenaga kerja ini, secara eksplisit disebutkan dalam Keputusan Mendikbud Nomor 0490/U/1992 tentang Unit Produksi pada pasal 29, "Setiap SMK mengusahakan penyelenggaraan unit produksi yang bertujuan meningkatkan kualitas lulusan dan kemampuan tenaga kependidikan, serta untuk menambah modal pembiayaan penyelenggaraan pendidikan". Hal ini menunjukkan bahwa unit produksi merupakan program pemerintah dalam upaya untuk memajukan SMK sehingga perlu dibuat aturan dan acuan agar dapat dilaksanakan dengan sebaik-baiknya oleh pihak sekolah.

Bambang Sartono dalam PMPTK Depdiknas (2007, p.6) menyebutkan Unit Produksi/Jasa SMK/MAK ialah suatu proses kegiatan usaha yang dilakukan sekolah/madrasah secara berkesinambungan, bersifat akademis dan bisnis dengan memberdayakan warga sekolah/ madrasah dan lingkungan dalam bentuk unit usaha produksi/jasa yang dikelola secara profesional. Direktorat Pembinaan SMK (2007, p.1) menyatakan "Unit Produksi merupakan suatu sarana pembelajaran dan berwirausaha bagi siswa dan guru serta memberi dukungan biaya operasional sekolah". Berdasarkan beberapa pengertian tersebut dapat disimpulkan bahwa Unit Produksi merupakan unit usaha yang dimiliki oleh unit usaha yang berada di lingkungan organisasi sekolah bertujuan untuk meningkatkan kompetensi siswa dan memproduksi barang serta jasa yang dapat dipasarkan. Selanjutnya keuntungan yang diperoleh dari hasil pemasaran tersebut digunakan untuk membantu pembiayaan sekolah dan meningkatkan kesejahteraan warga sekolah.

Unit produksi sekolah merupakan ciri khas SMK, yang membedakan sekolahnya dengan SMU. Unit produksi diperlukan sebagai wahana pelatihan siswa dalam memberikan pengalaman langsung pada sebuah kegiatan usaha, agar siswa dapat menjadi manusia yang mandiri. Dengan demikian, fungsi unit produksi/jasa sekolah ini adalah sebagai sumber belajar siswa untuk menjadi wirausaha yang sukses.

Agar unit produksi sekolah dapat menjadi sumber pembelajaran dan pendanaan maka perlu dikelola secara profesional. Hakikatnya Unit Produksi merupakan bagian terpenting dari pendidikan kejuruan (dalam hal ini SMK) yang wajib dikelola dengan baik meliputi perencanaan, pengorganisasian, pelaksanaan, dan pengawasan, Di samping itu, unit produksi akan memberikan keuntungan, seperti dijelaskan pada strategi Dikmenjur 2000-2005 (Mahfud, T \& Pardjono, 2012, p.30), keuntungannya meliputi: (1) menambah penghasilan SMK yang dapat digunakan untuk meningkatkan kesejahteraan warganya; (2) memperbaiki dan meremajakan fasilitas sekolah; (3)mendekatkan relevansi program kejuruan dengan kebutuhan dunia industri; dan(4) menyiapkan siswa berlatih kerja secara nyata dan bertanggung jawab, karena hasil kerjanya akan dijual di pasaran umum.

Kenyataan di lapangan, ternyata di Kabupaten Sleman, ada 12 SMK dengan Program Studi Keahlian Tata Busana dan hanya sekitar dua sekolah yang mempunyai unit produksi aktif, selebihnya tidak berjalan dengan baik atau bahkan hanya nama saja. Tentu hal ini menjadi permasalahan yang penting yang harus dicari solusinya. Di satu sisi, 
pelaksanaan Unit Produksi di SMK sebagai sarana pembelajaran yang mengacu pada dunia kerja yang nyata, namun di sisi lain, proses pembelajaran itu diharapkan dapat dihasilkan suatu produk/jasa yang mempunyai nilai jual, memberikan nilai finansial, yang bertujuan agar bisa memberikan kontribusi bagi penyelenggara pendidikan. Hasil belajar yang dicapai siswa SMK akan bernilai jika dapat diakui oleh masyarakat sebagai sesuatu yang bermanfaat dan laku dijual.

Unit Produksi SMK saat ini masih terkendala masalah yang berkaitan dengan pemasaran produk/jasa hasil praktik siswa. Hal yang masih banyak terjadi adalah produk/ jasa yang dipasarkan Unit Produksi bukan merupakan hasil karya siswa namun hasil produksi pihak lain, misal karyawan Unit Produksi, alumni atau guru.

Berdasarkan uraian tersebut, maka permasalahan penelitian ini dapat dirumuskan: (1) faktor-faktor apa saja yang menjadi kendala pelaksanaan Unit Produksi SMK Program Studi Keahlian Tata Busana selama ini?; (2) model manajemen Unit Produksi seperti apakah yang layak untuk SMK Program Studi Keahlian Tata Busana di Kabupaten Sleman?; dan (3) bagaimanakah kelayakan model manajemen Unit Produksi SMK Program studi Keahlian Tata Busana yang dihasilkan?

Adapun tujuan yang diharapkan pada penelitian ini yakni: (1) mengetahui faktorfaktor penghambat pelaksanaan Unit Produksi SMK Program Studi Keahlian Tata Busana di Kabupaten Sleman selama ini; (2) menghasilkan model manajemen Unit Produksi yang layak untuk diterapkan pada SMK Program Studi Keahlian Tata Busana; dan (3) menguji coba kelayakan model manajemen Unit Produksi SMK Program Studi keahlian Tata Busana

Penelitian ini diharapkan dapat memberikan manfaat bagi: (1) Direktorat Jenderal Pembinaan Sekolah Menengah Kejuruan, penelitian ini dapat dijadikan masukan dan bahan pertimbangan dalam mengevaluasi kebijakan peningkatan mutu pendidikan di SMK melalui penyelenggaraan Unit Produksi secara profesional; (2) bagi pengelola unit produksi, penelitian ini dapat dijadikan sebagai informasi alternatif sehingga ke depan mampu mengelola Unit Produksi sekolah seperti halnya mengelola perusahaan tanpa meninggalkan manfaat edukasi, ekonomi dan sosial; dan (3) terwujudnya Unit Produksi sekolah yang profesional sehingga mampu memberikan manfaat yang positif bagi sekolah

\section{METODE PENELITIAN}

Studi ini menggunakan model Penelitian dan Pengembangan (Research and Development). Sesuai dengan prosedur penelitian dan pengembangan oleh Borg \& Gall (1983, p.775), maka tahapan pada penelitian ini dikonversi dari sepuluh tahap menjadi tiga tahap. Untuk tahap yang kesepuluh yakni tahap dissemination and implementation akan dilakukan pada penelitian selanjutnya.

Adapun tahap pertama yang dilakukan yakni penelitian dan pengumpulan informasi. Tahap kedua melakukan perencanaan model. Tahap ketiga melakukan pengembangan model. Pada tahap penelitian dan pengumpulan informasi dilakukan pengumpulan data dan informasi dari lapangan yang telah ditetapkan. Data dan informasi yang diperoleh digunakan sebagai dasar untuk mengembangkan model awal manajemen Unit Produksi SMK. Selain berdasar pada data dan informasi dari lapangan, pengembangan model awal tersebut, data dan informasi juga diperoleh melalui kajian literatur yang relevan dengan teori, hasil penelitian, dan peraturan perundang-undangan tentang Unit Produksi di SMK. Adapun kegiatan yang dilakukan pada tahap ini antara lain: (1) merumuskan tujuan, kegunaan, dan peranan hasil penelitian; (2) melakukan studi literatur; dan (3) menentukan setting penelitian

Lokasi penelitian yang dipilih adalah empat SMK Bidang Keahlian Kelom-pok Bisnis, Pariwisata dan Seni di Kabupaten Sleman. Sekolah tersebut terdiri dari: SMK Negeri 2 Godean, SMK Negeri 1 Depok, SMK Muhammadiyah Berbah, dan SMK Karya Rini.

Penelitian ini dilaksanakan bulan Desember 2014 sampai dengan Maret 2015. Bulan Desember 2014-Januari 2015 digunakan untuk menganalisis kebutuhan, JanuariFebruari 2015 untuk mengembangkan model manajemen Unit Produksi SMK, sedangkan Februari - April 2015 digunakan untuk uji coba/ validasi model dan uji. 
Dimensi kegiatan dalam penelitian ini yakni manajemen Unit Produksi yang terdiri dari Unit Produksi sebagai sumber belajar dan Unit Produksi sebagai sumber pendanaan. Kegiatan Unit Produksi sebagai sumber belajar dan Unit Produksi sebagai sumber pendanaan dilihat dari fungsi manajemen POAC (Planning, Organizing, Actuating, and Controlling).

Sumber data berasal dari kepala sekolah, Ketua Program Studi Keahlian Tata Busana, Bendahara Unit Produksi, dan Ketua Unit Produksi. Jenis data yang dijaring berkaitan dengan manajemen Unit Produksi SMK Program Studi Keahlian Tata Busana

Teknik pengumpulan data yang digunakan dalam penelitian ini adalah: observasi langsung di lokasi penelitian dengan dibantu alat perekam gambar dan suara, wawancara mendalam kepada semua informan yang telah ditentukan. Di samping itu, dilakukan kajian dokumen yang ada di sekolah yang meliputi: visi dan misi Unit Produksi, susunan organisasi, tata tertib Unit Produksi, dan data lain yang dibutuhkan.

Instrumen dalam penelitian ini adalah peneliti sendiri. Namun, setelah fokus penelitian menjadi jelas dikembangkan instrumen lain yang lebih sederhana, yang diharapkan dapat digunakan untuk menjaring data yang lebih tajam dan luas untuk melengkapi hasil observasi.

Pengujian keabsahan data pada penelitian ini menggunakan triangulasi sumber. Dalam hal ini triangulasi dilakukan dengan cara membandingkan antarinformasi yang diperoleh dari infor-man pertama, informan kedua,dan seterusnya. Data yang didapat yang merupakan hasil wawancara, pengamatan, dan dokumentasi dianalisis dan diinterpretasi untuk memenuhi tuntutan tujuan penelitian dan informasi lainnya.

Pada tahap perencanaan model difokuskan untuk (1) merumuskan tujuan pembentukan model, dalam hal ini yaitu manajemen Unit Produksi SMK Program Studi Keahlian Tata Busana; (2) menetapkan sasaran pengguna model, yaitu pimpinan dan pengelola Unit Produksi yang dapat memanfaatkan dalam hal pengembangan manajemen Unit Produksi; (3) dan menetapkan komponen model, yakni komponen-komponen model yang memudahkan pengguna untuk melaksanakan model. Dalam hal ini adalah komponen manajemen Unit Produksi berisi Unit Produksi sebagai sumber belajar dan Unit Produksi sebagai sumber pendanaan, kejelasan struktur komponen model, kejelasan hubungan antar komponen model pengembangan sumber dana sekolah, keterbacaan model, dan kelayakan model.

Pada tahap pengembangan model dilakukan hal-hal berikut ini: (1) validasi model tahap pertama; (2) revisi model; (3) validasi model tahap kedua; dan (4) revisi model operasional. Kriteria validasi model diukur berdasarkan berdasarkan pada enam variabel/ spesifikasi model yaitu: kelengkapan komponen model, kejelasan struktur komponen model, kejelasan hubungan antar komponen model, keterbacaan model, kelayakan model, dan keefektifan model jika diimplementasikan.

Uji coba model dilakukan dalam dua tahap yaitu tahap expert judgement dan tahap uji keefektifan model. Tahap expert judgement yaitu meminta sejumlah orang yang memiliki kepakaran di bidang pengembangan model manajemen Unit Produksi SMK Program Studi Keahlian Tata Busana untuk memberikan penilaian terhadap model yang telah dikembangkan. Adapun langkah yang dilakukan sebagai berikut: (1) menentukan model pengembangan manajemen Unit Produksi SMK Program Studi Keahlian Tata Busana hasil pengembangan sebelumnya; (2) menetapkan anggota panelis berdasarkan pada bidang kepakaran; (3) menyiapkan butir-butir instrument berdasarkan pada variabel model yang dikemukakan; (4) mengirimkan kuesioner pada jawaban instrument dan memperbaiki model untuk dikembalikan; (5) mengirim kembali model yang diperbaiki untuk ditelaah; (6) peneliti mengundang panelis untuk melakukan klarifikasi dan diskusi terhadap jawaban-jawaban dan catatan revisi yang dikemukakan sehingga dicapai konsensus; dan (7) membuat laporan.

Uji coba keefektifan model dimaksudkan untuk menguji tingkat keefektifan model dalam penggunaannya. Sasaran uji coba dipilih berdasarkan responden yang memiliki kepakaran dalam bidang penerapan model manajemen Unit Produksi SMK Program Studi Keahlian Tata Busana. Uji coba keefektifan model digunakan kuesioner yang berisi pendapat/persepsi responden terhadap keefektifan model yang diajukan. Karena model ini belum 
diterapkan untuk pelaksanaan yang sebenarnya maka disebut keefektifan internal.

\section{HASIL PENELITIAN DAN PEMBAHASAN}

Berdasarkan pemaparan terkait manajemen Unit Produksi yang terjadi pada setiap SMK maka ditemukan beberapa permasalahan dan kelemahan yang sering terjadi pada manajemen Unit Produksi sehingga hasil yang diperoleh dari pelaksanaan manajemen Unit Produksi kurang maksimal, permasalahan tersebut yaitu: pertama, tidak semua sekolah swasta memiliki sarana gedung yang memadai untuk digunakan sebagai Unit Produksi. Padahal sarana merupakan salah satu wujud pokok yang menyatakan bahwa Unit Produksi di SMK tersebut ada. Kedua, perencanaan Unit Produksi yang masih bersifat monoton. Artinya, Unit Produksi hanya dipandang untuk kesejahteraan warga dan sebagai wadah praktik siswa industri apabila tidak ada industri yang siap menerima siswa. Ketiga, pengorganisasian yang masih tumpang tindih. Banyak sekolah yang mempunyai anggota organisasi Unit Produksi yang masih merangkap jabatan organisasi lainnya di sekolah. Hal ini mengakibatkan anggota tidak fokus bekerja. Di beberapa sekolah, anggota organisasi Unit Produksi bukan merupakan ahli di bidang Tata Busana. Hal ini mengakibatkan kurang berkembangnya Unit Produksi karena pihak pengelola tidak kompeten di bidangnya. Organisasi Unit Produksi di beberapa sekolah hanya berupa formalitas saja untuk kepentingan akreditasi sekolah sehingga tidak ada wujud nyata dari susunan organisasi.

Keempat, pelaksanaan pembelajaran di Unit Produksi tidak berjalan di beberapa sekolah. Hal ini terjadi karena guru Tata Busana tidak bisa fokus mengajar siswa di kelas dan di Unit Produksi. Di samping itu, kurangnya tenaga pengajar yang mempunyai loyalitas tinggi terhadap pengelolaan Unit Produksi. Hal ini mengakibatkan tidak adanya kekompakan antarpersonal. Kelima, masyarakat luar sekolah masih kurang percaya dengan hasil jahitan dari Unit Produksi. Hal tersebut terjadi karena masyarakat berpendapat bahwa kain mereka digunakan siswa untuk praktik di Unit Produksi, sehingga hasil jahitan kurang maksimal. Penentuan harga jasa jahitan ataupun permak belum secara profesional karena kebanyakan konsumen individu berasal dari warga sekolah (kepala sekolah, guru, dan karyawan). Mereka meminta harga yang di bawah standar. Selain itu, SMK swasta merasa kekurangan dana ketika akan memproduksi dalam jumlah banyak. Keenam, di beberapa SMK swasta, hasil dari Unit Produksi digunakan untuk membiayai kegiatan ekstrakurikuler. Hal ini menyebabkan pembagian fee untuk kesejahteraan pengelola Unit Produksi tidak ada. Padahal untuk kegiatan ekstrakurikuler, pihak sekolah menarik iuran langsung dari siswa.

Keenam, pengawasan Unit Produksi di SMK negeri langsung dari BPK, sehingga pihak sekolah merasa keberatan apabila hasil Unit Produksi harus disetor ke kas Negara. Hal ini mengakibatkan pihak pengelola bekerja kurang optimal, sedangkan di SMK Swasta, pengawasan hanya dilakukan oleh Kepala Sekolah.

Oleh karena itu, langkah untuk menjembatani permasalahan yang terjadi di manajemen Unit Produksi SMK yang ada selama ini, diperlukan suatu pengembangan model manajemen Unit Produksi. Hasil pengembangan model manajemen Unit Produksi SMK ini diharapkan dapat menjadi solusi untuk mencapai tujuan ideal dari kegiatan Unit Produksi dan layak untuk diterapkan di SMK. Selain itu, melalui pengembangan model manajemen Unit Produksi SMK ini juga dapat memiliki implikasi: (1) bagi Direktorat Jenderal Pembinaan Sekolah Menengah Kejuruan, penelitian ini dapat dijadikan masukan dan bahan pertimbangan dalam mengevaluasi kebijakan peningkatan mutu pendidikan di SMK melalui penyelenggaraan Unit Produksi secara profesional; (2) bagi pengelola unit produksi, penelitian ini dapat dijadikan sebagai informasi alternatif sehingga ke depan mampu mengelola Unit Produksi sekolah seperti halnya mengelola perusahaan tanpa meninggalkan manfaat edukasi, ekonomi dan sosial; dan (3) terwujudnya Unit Produksi sekolah yang profesional sehingga mampu memberikan manfaat yang positif kepada sekolah

Adapun pengembangan model manajemen Unit Produksi SMK ini dititikberatkan pada dua komponen pendukung manajemen Unit Produksi yakni Unit Produksi sebagai sumber belajar dan Unit Produksi sebagai sumber pendanaan. Isi dari komponen Unit produksi sebagai sumber belajar terdiri dari 
empat aspek manajemen yakni: (1) perencanaan yang terdiri dari visi, misi, dan tujuan yang jelas sebagai langkah awal pembentukan Unit Produksi; (2) pengorganisasian terdiri dari pedoman penyusunan organisasi, struktur organisasi, dan job descriptions; (3) pelaksanaan terdiri dari pembagian tugas guru, pembagian tugas tenaga pendidik, silabus-RPP, dan tata tertib pembelajaran di Unit Produksi; dan (4) pengawasan terdiri dari pengawasan terhadap peserta didik, evaluasi internal unit produksi, dan evaluasi pendidik-tenaga pendidikan.

Unit Produksi sebagai sumber pendanaan terdiri dari empat aspek manajemen yakni: (1) perencanaan yang terdiri dari: desain analisis lingkungan bisnis, gambaran produk jasa, analisis persaingan, strategi harga, gambaran keunggulan kompetitif Unit Produksi SMK, gambaran metode segmentasi pasar yang digunakan, gambaran lokasi, gambaran rencana promosi, identifikasi manajemen dan personel, resiko yang tidak dapat diramalkan, dan identifikasi penyuplai bahan baku; (2) pengorganisasian dibuat struktur organisasi dan job description; (3) pelaksanaan yang terdiri dari: kegiatan pelayanan prima, pengaturan waktu operasi Unit Produksi, pengaturan personel produksi, lay out produksi, peralatan penunjang produksi dan pengelolaan pemasaran; dan (4) pengawasan yang terdiri dari pengawasan terhadap biaya, mutu, dan waktu produksi, pengawasan personal dan pengajuan klaim-sanksi.

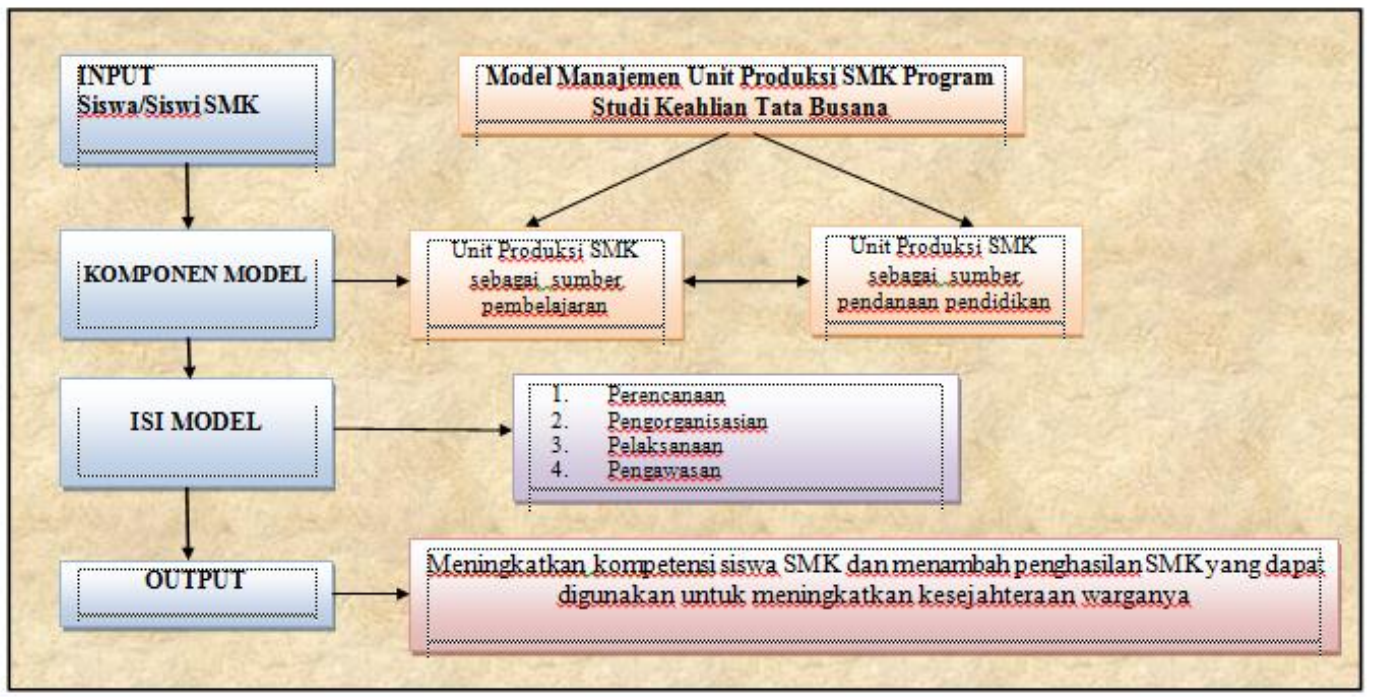

Gambar 1. Konsep Model Manajemen Unit Produksi SMK

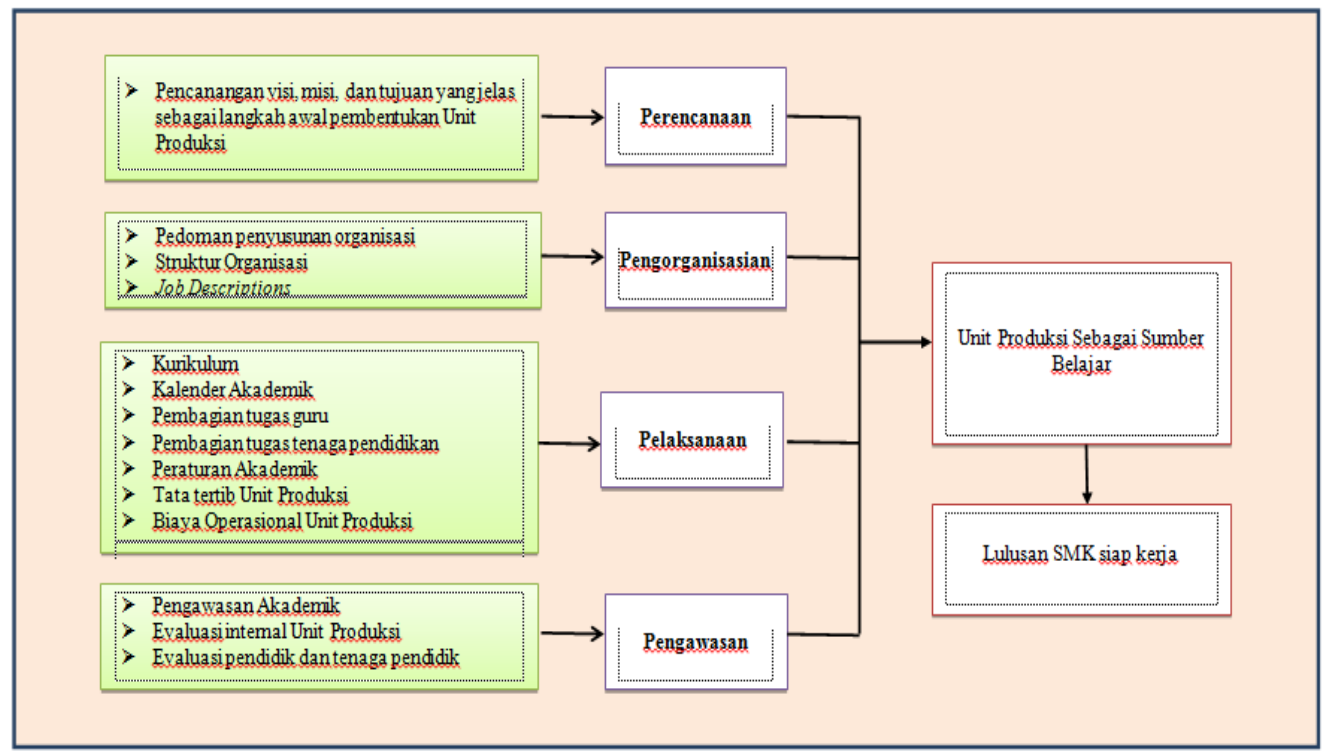

Gambar 2. Konsep Komponen Unit Produksi sebagai Sumber Belajar 


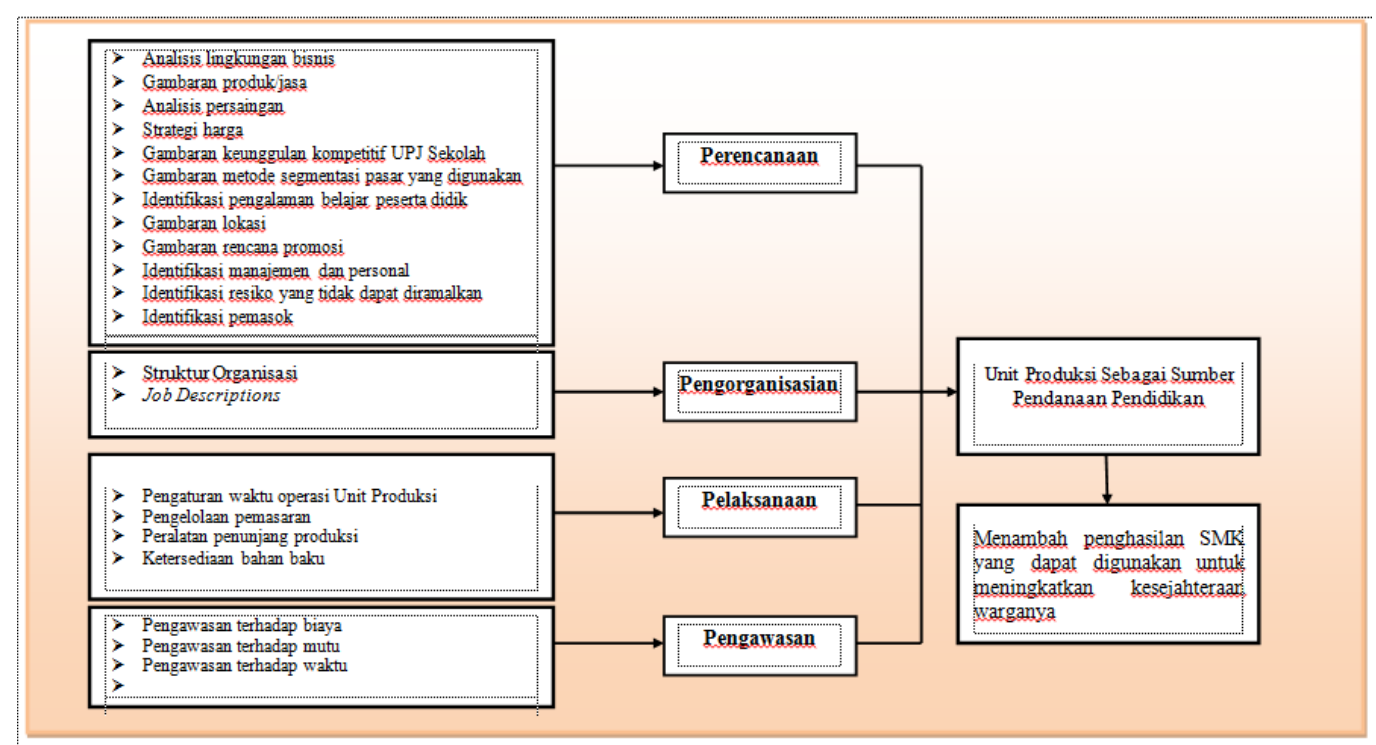

Gambar 3. Konsep Komponen Unit Produksi sebagai Sumber Pendanaan

\section{Hasil Pengembangan Produk Awal}

\section{Model manajemen Unit Produksi SMK}

Berdasarkan penjelasan teori dan konsep Unit Produksid irumuskan Model manajemen Unit Produksi yang terdiri dari komponen Unit Produksi sebagai sumber belajar dan Unit Produksi sebagai sumber pendanaan. Seluruh komponen tersebut tidak dapat dipisahkan antara satu dan lainnya. Melalui unit produksi, para siswa belajar berbagai pengalaman mengoperasikan usaha. Mereka belajar tentang bagaimana merencanakan, melaksanakan dan mengawasi jalannya unit produksi. Bagaimana mempelajari selera pelanggan, merencanakan produk, kelayakan produk, administrasi keuangan, teknik pemasaran, teknik bernegosiasi, pelayanan terhadap pelanggan dan lainnya.

\section{Komponen Unit Produksi sebagai Sumber Belajar}

Dari berbagai aktivitas belajar di Unit Produksi dapat diperoleh keterampilan, pengetahuan, dan pengalaman langsung yang bermanfaat bagi perkembangan peserta didik. Pengalaman belajar nyata tersebut dapat meningkatkan berbagai pengetahuan keterampilan antara lain kemampuan menjual, teknik berkomunikasi, keterampilan memproduksi, menganalisis peluang usaha, mendesain produk, merencanakan usaha, menghitung atau mengambil resiko, dan lain sebagainya. Selain itu, peserta didik belajar tentang kejujuran, keuletan, kemandirian, menghargai waktu, menghormati orang, teliti, bertanggung jawab dan berbagai sifat wirausaha lainnya.

\section{Komponen Unit Produksi sebagai Sumber Pendanaan}

Unit Produksi sebagai sumber pendanaan merupakan salah satu cara memaksimalkan salah satu potensi yang dimiliki oleh sekolah. Melalui wadah Unit Produksi, segala hasil kreativitas siswa dan hasil dari kompetensi siswa dapat memiliki nilai jual yang berguna untuk meningkatkan kesejahteraan seluruh warga sekolah.

\section{Hasil Ujicoba Produk}

Validasi model dimaksudkan untuk mendapat gambaran atau informasi mengenai (1) kelengkapan komponen model; (2) kejelasan struktur komponen model; (3) kejelasan hubungan antarkomponen; (4) keterbacaan model dengan baik; (5) kelayakan model; dan (6) keefektifan jika diimplementasikan. Validasi dilakukan oleh pakar pakar manajemen Unit Produksi, Dr. Moch. Bruri Triyono, dan pakar Kompetensi Keahlian Tata Busana, Dr. Emy Budiastuti.

Menurut pandangan para ahli manajemen pendidikan dan praktisi Unit Produksi di SMK, pengembangan model manajemen Unit Produksi Program Studi Tata Busana di SMK dapat diterima dan dapat digunakan di lapangan dengan beberapa perbaikan dan penyempurnaan, mulai dari model secara keseluruhan yaitu: (1) penggambaran hubungan antarkomponen perlu direvisi. Penggambaran arah 
panah dari kedua komponen model harus menyatu ke isi model dan berakhir di output; dan (2) Output dari model diperjelas menjadi meningkatkan kompetensi siswa dan menambah penghasilan SMK.

Pada Gambar 1 yakni kompoen Unit Produksi sebagai sumber belajar terdapat beberapa perbaikan dan penyempurnaan yaitu: (1) indikator kurikulum dan kalender pada fungsi pelaksanaan Unit Produksi sebagai sumber belajar sebaiknya ditiadakan karena dianggap ada double kurikulum di sekolah; (2) perlu diperjelas penulisan kalimat tata tertib Unit Produksi menjadi tata tertib pembelajaran di Unit Produksi; (3) indikator biaya operasional Unit Produksi ditiadakan; (4) indikator pengawasan akademik diganti monitoring peserta didik; dan (5) indikator evaluasi internal Unit Produksi diganti menjadi evaluasi hasil produk siswa.
Pada Gambar 2, yakni komponen Unit Produksi sebagai sumber pendanaan terdapat beberapa perbaikan dan penyempurnaan yaitu: (1) indikator identifikasi pengalaman belajar siswa untuk Unit Produksi sebagai sumber pendanaan ditiadakan; (2) indikator identifikasi pemasok diganti menjadi identifikasi penyuplai bahan baku; (3) penambahan indikator pelayan prima, layout produksi, dan quality control; (4) penambahan pengajuan klaim dan sanksi.

\section{Uji coba di Lapangan}

Uji coba di lapangan dilakukan dengan meminta masukan dari praktisi pendidikan, khususnya pengelola SMK mengenai model yang telah dirancang. Berdasarkan wawancara yang telah dilakukan di empat SMK dapat disimpulkan pada Tabel 1 dan 2 .

Tabel 1. Kesimpulan Uji coba Model di Lapangan

\begin{tabular}{llll}
\hline No & Variabel Model & Kesimpulan \\
\hline $1 \quad$ Manajemen Unit Produksi SMK & $>$ & Perlu diperjelas model ini dapat digunakan untuk SMK \\
& Program Studi Tata Busana & swasta atau negeri
\end{tabular}

Tabel 2. Persentase Hasil Validasi Model

\begin{tabular}{|c|c|c|c|c|c|}
\hline No & Uraian Variabel Model & $\begin{array}{l}\text { Persentase masing- } \\
\text { masing komponen } \\
\text { model }(\%)\end{array}$ & $\begin{array}{c}\text { Model Manajemen } \\
\text { Unit Produksi SMK } \\
\text { Prodi Tata Busana }\end{array}$ & $\begin{array}{l}\text { Unit produksi } \\
\text { sebagai Sumber } \\
\text { Belajar }\end{array}$ & $\begin{array}{c}\text { Unit Produksi } \\
\text { sebagai sumber } \\
\text { pendanaan }\end{array}$ \\
\hline \multirow{3}{*}{1} & \multirow{3}{*}{$\begin{array}{l}\text { Kelengkapan } \\
\text { Komponen Model }\end{array}$} & TS & 0 & 0 & 0 \\
\hline & & $\mathrm{S}$ & 50 & 100 & 100 \\
\hline & & $\mathrm{R}$ & 50 & 0 & 0 \\
\hline \multirow{3}{*}{2} & \multirow{3}{*}{$\begin{array}{l}\text { Kejelasan Struktur } \\
\text { Komponen Model }\end{array}$} & TS & 0 & 0 & 0 \\
\hline & & S & 75 & 100 & 100 \\
\hline & & $\mathrm{R}$ & 25 & 0 & 0 \\
\hline \multirow{3}{*}{3} & \multirow{3}{*}{$\begin{array}{l}\text { Kejelasan Hubungan } \\
\text { antarKomponen Model }\end{array}$} & TS & 0 & 0 & 0 \\
\hline & & $\mathrm{S}$ & 75 & 100 & 100 \\
\hline & & $\mathrm{R}$ & 25 & 0 & 0 \\
\hline \multirow{3}{*}{4} & \multirow{3}{*}{ Keterbacaan Model } & $\mathrm{TS}$ & 0 & 0 & 0 \\
\hline & & S & 75 & 75 & 75 \\
\hline & & $\mathrm{R}$ & 25 & 25 & 25 \\
\hline \multirow{3}{*}{5} & \multirow{3}{*}{ Kelayakan Model } & TS & 0 & 0 & 0 \\
\hline & & $S$ & 50 & 50 & 50 \\
\hline & & $\mathrm{R}$ & 50 & 50 & 50 \\
\hline \multirow{3}{*}{6} & \multirow{3}{*}{$\begin{array}{l}\text { Keefektifan Model jika } \\
\text { Diimplementasikan }\end{array}$} & TS & 50 & 50 & 50 \\
\hline & & $\mathrm{S}$ & 50 & 50 & 50 \\
\hline & & $\mathrm{R}$ & 0 & 0 & 0 \\
\hline
\end{tabular}


Dari data hasil uji validitas tersebut dapat disimpulkan tingkat keefektifan model manajemen Unit Produksi yaitu: (1) sebesar 83,3\% Ahli setuju bahwa komponen model telah lengkap; (2) sebesar 91,7\% Ahli setuju bahwa struktur komponen model telah jelas; (3) sebesar $91,7 \%$ Ahli setuju bahwa hubungan antarkomponen model telah jelas; (4) sebesar 75\% Ahli setuju bahwa model memiliki keterbacaan yang baik; (5) sebesar 50\% Ahli setuju bahwa model telah layak; dan (6) sebesar 50\% Ahli setuju bahwa model efektif jika diimplementasikan.

\section{Revisi Produk}

Sejak berbentuk rancangan model berupa draf pengembangan sampai dengan menjadi produk akhir,rancangan model mengalami beberapa kali revisi. Akhirnya, didapatkan model yang benar-benar layak dapat diselenggarakan di SMK.

Revisi pertama: dilakukan setelah draf pengembangan dikaji bersama dalam diskusi bersama para pakar pendidikan kejuruan dan teman sejawat. Dalam diskusi dinyatakan bahwa dalam draf pengembangan belum menjelaskan variabel yang membedakan model manajemen Unit Produksi yang sudah ada dan belum memunculkan fungsi manajemen secara lengkap. Berdasarkan masukan dan berbagai pendapat dalam diskusi ini diperoleh Model Hipotetik

Revisi kedua: setelah diperoleh model hipotetik, lalu dilakukan uji coba pendahuluan dengan uji ahli (Putaran I). Uji coba pendahuluan ini diterapkan kepada dua subjek coba yang terdiri dari pakar manajemen pendidikan dan praktisi pendidikan bidang studi Tata Busana. Berdasarkan uji ahli ini, model hipo- tetik direvisi lagi sehingga diperoleh model hasil uji ahli Putaran I. Dari gambar model ini terlihat bahwa Unit Produksi SMK mempunyai dua variabel yang dapat mencapai tujuan Unit Produksi. Selain itu, ada beberapa indikator pendukung yang dapat menunjang Unit Produksi sebagai sumber belajar dan Unit Produksi sebagai sumber pendanaan

Revisi ketiga: model hasil Putaran I dilakukan pengujian internal dengan menerapkan pada empat subjek coba yang terdiri dari Kaprodi Tata Busana dan Pengelola Unit Produksi. Berdasarkan pengujian internal didapat bahwa manajemen Unit Produksi di SMK Negeri dan swasta membutuhkan regulasi yang jelas sehingga menghasilkan Unit Produksi yang bisa meningkatkan kompetensi siswa dan menghasilkan sumber dana tambahan.

\section{Kajian Produk Akhir}

Pengembangan model manajemen Unit Produksi SMK Program Studi Keahlian Tata Busana merupakan model manajemen Unit Produksi yang dapat dilakukan SMK sehingga dapat memaksimalkan potensi siswa, guru, dan sekolah yang dapat meningkatkan kompetensi siswa serta menghasilkan income generating. Pengembangan model manajemen Unit Produksi SMK Program Studi Keahlian Tata Busana ini telah diuji secara kualitatif dan hasilnya menunjukkan bahwa model ini cukup jelas, praktis dan sesuai untuk Program Studi Tata Busana. Adapun penjelasan dan karakteristik Pengembangan Model Manajemen Unit Produksi SMK Program Studi Tata Busana antara lain:

\section{Model Akhir Manajemen Unit Produksi SMK}

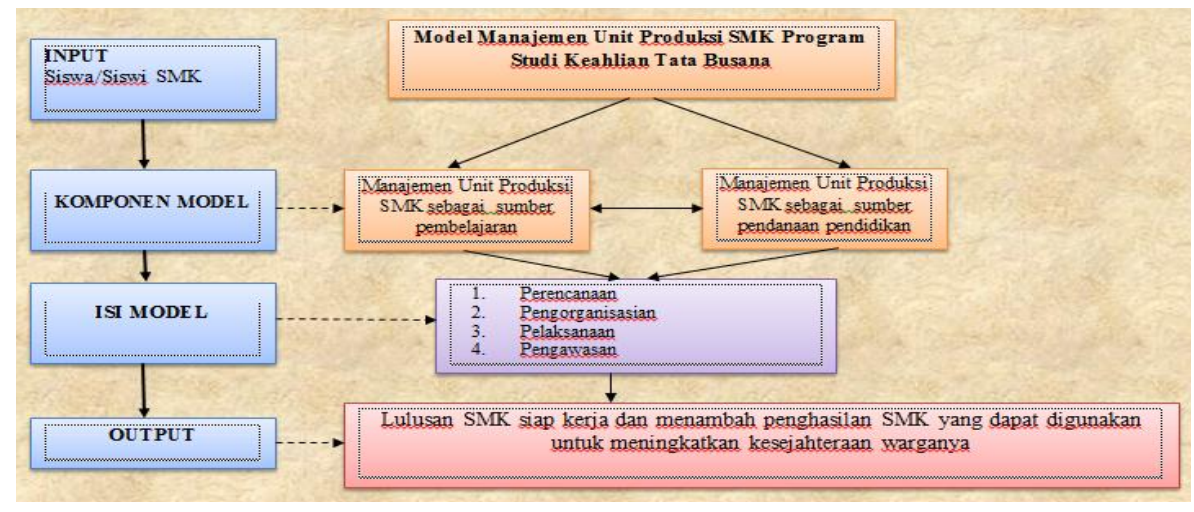

Gambar 4. Model Akhir Manajemen Unit Produksi SMK 
Komponen Unit Produksi sebagai Sumber Belajar

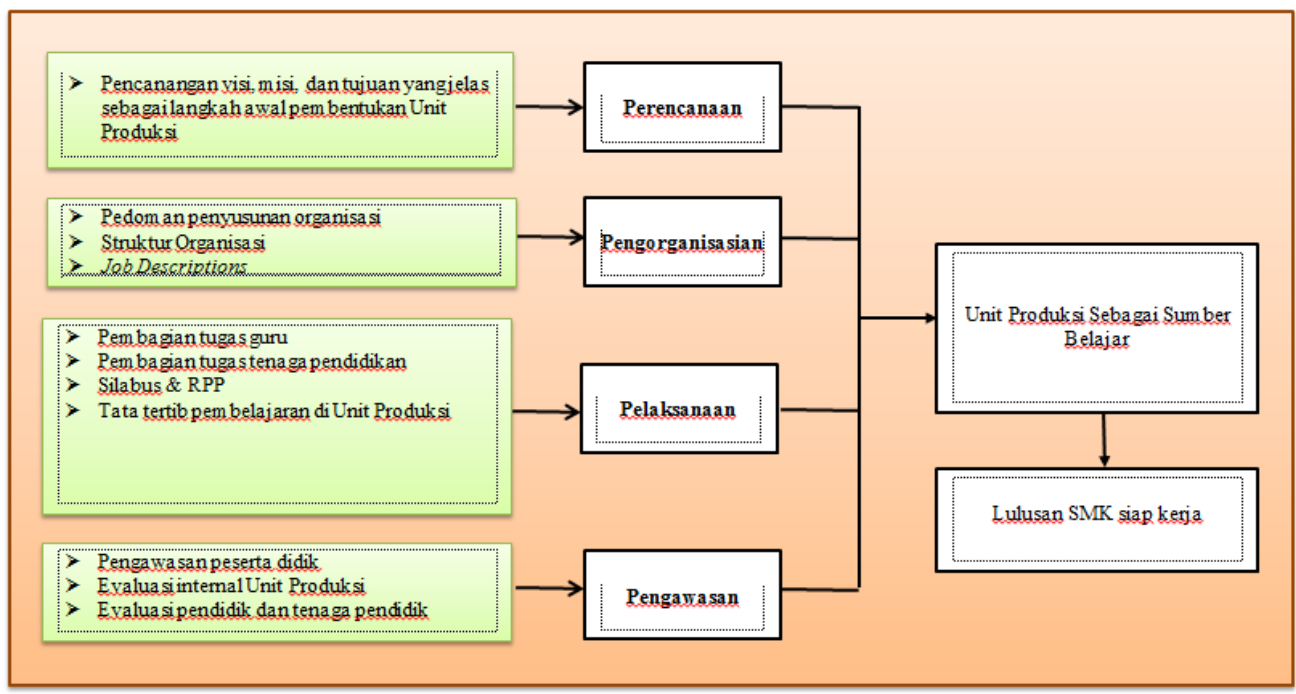

Gambar 5. Komponen Akhir Unit Produksi sebagai Sumber Belajar

\section{Komponen Unit Produksi sebagai Sumber Pendanaan}

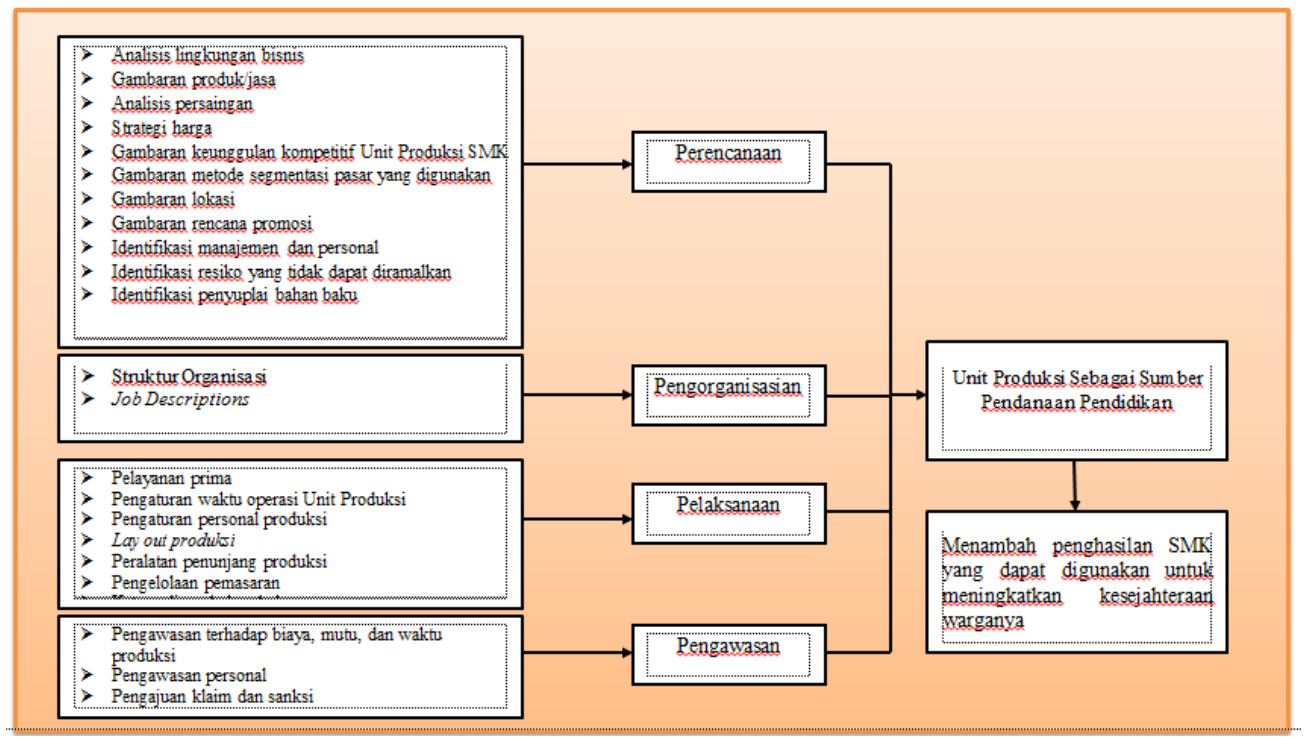

Gambar 6. Komponen Akhir Unit Produksi sebagai Sumber Pendanaan

\section{SIMPULAN DAN SARAN}

\section{Simpulan}

Berdasarkan hasil penelitian yang sudah dibahas tersebut, maka dapat disimpulkan hasil sebagai berikut:

Pertama, hasil penelitian menunjukkan bahwa pelaksanaan manajemen Unit Produksi SMK program studi Tata Busana masih terdapat beberapa kendala sebagai berikut: (1) tidak semua sekolah swasta memiliki sarana gedung yang memadai untuk digunakan sebagai Unit Produksi; (2) perencanaan Unit produksi yang masih monoton; (3) job description yang masih tumpang tindih; (4) organisasi Unit Produksi di beberapa sekolah hanya berupa formalitas saja untuk kepentingan akreditasi sekolah; (5) pelaksanaan pembelajaran di Unit Produksi tidak berjalan di beberapa sekolah; (6) masyarakat luar sekolah masih kurang percaya dengan hasil jahitan dari Unit Produksi; (7) pengawasan Unit Produksi yang tidak maksimal; (8) SMK swasta merasa kekurangan dana ketika akan memproduksi dalam jumlah 
banyak; dan (9) pengawasan Unit Produksi di SMK Negeri langsung dari BPK, sehingga pihak sekolah merasa keberatan apabila hasil Unit Produksi harus disetor ke Kas Negara

Kedua, menghasilkan model manajemen Unit Produksi yang layak untuk diterapkan di SMK Program Studi Keahlian Tata Busana terdiri dari dua komponen yaitu: (1) Unit Produksi sebagai sumber belajar, dan (2) Unit Produksi sebagai sumber pendanaan.

Ketiga, hasil uji kelayakan model yang dilakukan terhadap pengelola SMK yang terdiri dari: SMK Negeri 1 Depok, SMK Negeri 2 Godean, SMK Karya Rini, dan SMK Muhammadiyah Berbah menyimpulkan bahwa: (1) komponen model telah lengkap; (2) struktur komponen model telah jelas; (3) hubungan antar komponen model telah jelas; (4) model memiliki keterbacaan yang baik; (5) model telah layak; dan (6) model efektif jika diimplementasikan.

\section{Saran Pemanfaatan Produk}

Produk pengembangan model manajemen Unit Produksi SMK Program Studi Keahlian Tata Busana disarankan untuk dimanfaatkan dalam hal: (1) menerapkan jiwa mandiri, disiplin dan kreatif siswa sehingga mewujudkan lulusan siap kerja; (2) pembelajaran aktif yang menghasilkan income generating. Selain meningkatkan kompetensi siswa di Unit Produksi, juga dapat meningkatkan sumber pendanaan; (3) pengembangan Unit Produksi dengan manajemen yang baik dapat menjadi karakteristik SMK yang dapat menjadi program unggulan sekolah; dan (4) regulasi yang jelas akan mempermudah dan mendukung pelaksanaan pengembangan model manajemen Unit Produksi SMK.

\section{Daftar Pustaka}

Borg, W.R \& Gall, M.D. (1983). Educational research an introduction. New York: Longman

Depdikbud (1993). Kepmendikbud Nomor $0490 l U I 1992$ tentang SMK. Jakarta: Depdikbud

Menteri Pendidikan Nasional. (2013). Peraturan Menteri Pendidikan dan Kebudayaan Nomor 54. Tahun 2013. Tentang Standar Kompetensi Lulusan Pendidikan dasar dan Menengah.

PMPTK Depdiknas (2007). Pedoman Manajemen Unit Produksi/Jasa sebagai Sumber Belajar Peserta Didik dan Penggalian Dana Pendidikan Persekolahan. Jakarta: Depdiknas

Mahfud, T \& Pardjono. (2012). Praksis Pembelajaran kewirausahaan Pada Unit Produksi Jasa Boga. Jurnal Pendidikan Vokasi.Vol. 2 No. 1. Halaman 30. 